\title{
The Effect of Net Trade Cycle, Firm Size, and Networking Capital on Profitability with Cash Holdings as Intervening Variables in Cement Companies in Indonesia
}

\author{
Jaya Irawan \\ Master of Management, Sriwijaya University, Palembang, Indonesia \\ Corresponding author email: jayairawan@gmail.com \\ Marlina Widiyanti \\ Lecturer of Magister Management, Economic Faculty, Sriwijaya University, Palembang, Indonesia \\ Email: marlinawidiyanti68@yahoo.co.id \\ Luk Luk Fuadah \\ Lecturer of Magister Management, Economic Faculty, Sriwijaya University, Palembang, Indonesia \\ Email:lukluk.fuadah@gmail.com \\ Isnurhadi \\ Lecturer of Magister Management, Economic Faculty, Sriwijaya University, Palembang, Indonesia \\ Email: isnurhadi@unsri.ac.id
}

\begin{abstract}
This study aims to examine a model that hypothesizes that the net trade cycle, company size, and net working capital of cement companies in Indonesia impact achieving a return on assets as a proxy for profitability through the company's cash holdings. The sample consists of 45 cement producers in Indonesia that have produced commercially before 2011 and regularly publish company annual reports. The results of the path analysis confirm that the net trade cycle, firm size, and networking capital do not affect the return on assets as a proxy for profitability. Likewise, statistically, it still shows the same results after being mediated with cash holdings. Moreover, found the effect of cash holdings on ROA. These findings can provide a starting point for further research to find a more appropriate formula to increase profitability, especially for companies in the cement sector in Indonesia, where utilization rates tend to be low, and market conditions are becoming very competitive.
\end{abstract}

Keywords---cash holdings, cement, company size, net trade cycle, net working capital, return assets

\section{Introduction}

The growth of the production capacity of the cement industry in Indonesia has been relatively rapid in the last ten years. The expansion of production capacity carried out by each cement company in Indonesia simultaneously increases the domestic cement production capacity. Each cement company carries out a production process optimization strategy that can increase the installed capacity of its existing plant by up to $20 \%$ more. In addition, during this period, cement companies invested in adding production units or building new factories (Kawakibi \& Hadiwidjojo, 2019). Investors' interest in constructing a new cement factory may be based on the trend of increasing domestic cement consumption, which is relatively rapid, reaching 13\% in 2009. Data from the Ministry of Industry shows that domestic cement consumption growth in 2011 reached $17.7 \%$ from the previous year's consumption. In addition, government policies are relatively encouraging and open vast opportunities for investors to invest in the 
country. By the mid-2010, Indonesia's cement industry had experienced excess capacity due to the company's investment in expanding production to take advantage of increasing demand. Furthermore, the government ordered cement SOEs to expand production outside Java to support regional development despite excess capacity at the national level (Kim, 2019).

This has encouraged cement companies, both old players and new players, to build new factories in Indonesia. With many new players in the national cement industry, market competition is increasingly competitive. Although several big players still dominate the market share, new players have controlled around 5\% of their leading market share after their production capacity was fulfilled in 2014-2015 (Prabowo \& Rusdiansyah, 2018). Moreover, after the new factories start commercial, the oversupply phase tends to start. The national installed capacity is greater than the national demand, which led to a price war and factory utilization, which was relatively below $70 \%$. The trend of ROA starting from 2012 is relatively declining. This phenomenon is followed by the cash holding of cement companies showing a downward trend since 2013. On the other hand, the size of cement companies has increased relatively because of investments that add value to assets. Meanwhile, working capital fluctuated. Subiyanto (2020), argues, although the company continues to lead the market on a large scale, the maximum performance achieved in 2013 is difficult to recover (Dongxue et al., 1997; Shiqun et al., 1999).

\section{Research Methods}

The population of this study Campbell (2014); Heale \& Twycross (2015); Qu \& Dumay (2011); Burawoy (2009) is cement companies operating in Indonesia. The research period covers the years 2012 to 2020. The research sample consisted of 5 selected companies that met the following criteria: (1) As a cement producer and operating commercially before 2011; (2) Regularly publish audited financial report data. The sample of this study resulted in forty-five (45) observations. Secondary data is obtained from annual reports that have been audited in the years concerned (Begley \& Boyd, 1987; Lepetit \& Strobel, 2013). The independent variable of this research is the net trade cycle indicator, company size, and the primary dependent variable is the profitability indicator. Like Niresh et al. (2014), has been carried out, total assets and total sales have been used as indicators of company size, while the ratio of net income and return on assets have been used to measure company profitability in this study.

Table 1

Variable measurements

\begin{tabular}{lc}
\hline \multicolumn{1}{c}{ Variable } & Formula \\
\hline Return on Assets (ROA) & $\frac{\text { Net Earnings }}{\text { Total Assets }}$ \\
Net Trade Cycle (NTC) & $\left(\frac{\text { Piutang }}{\text { Sales } \times 365}\right)+\left(\frac{\text { Inventory }}{\text { Cogs } \times 365}\right)-\left(\frac{\text { Utang }}{\text { Cogs } \times 365}\right)$ \\
Firm Size (SZ) & Ln(Total Assets) \\
Net Working Capital & (Current Assets - Cash \& Equivalent) Current Liabilities \\
Cash Holdings & $\begin{array}{c}\text { Total Assets } \\
\text { Cach \& Equivalent }\end{array}$ \\
\hline
\end{tabular}

IBM SPSS Statistics software version 25 was used to perform descriptive and correlation analysis.

\section{Results and Discussion}

Path analysis was conducted to explore the effect of the net trade cycle, firm size, and networking capital on return on assets through cash holdings. Without mediation, the direct effect between NTC and ROA showed an insignificant negative relationship of 0.35 ( $\mathrm{p}>0.05$ ) with (95\% confidence interval $-0.126 \sim 0.46$ ). Then $\mathrm{H}_{1}$ must be rejected. This result agrees with Nijam (2016); Yilmaz \& Acar (2019) who found an insignificant effect between NTC and ROA. Jakpar et al. (2017) also found that NTC hurt ROA in 164 manufacturing companies in Malaysia. The direct effect between SZ and ROA showed an insignificant negative relationship of 0.62 ( $P>0.05$ ) with (95\% confidence interval $-2.47 \sim 1.49$ ), then $\mathrm{H}_{2}$ should be accepted. Similar to the research results by Tawfeeq et al. (2018) in 65 selected companies in Jordan, a significant adverse effect was found between SZ and ROA. Meanwhile, the direct effect between NWC and ROA showed an insignificant positive relationship of 0.159 (p>0.05) with (95\% confidence interval -9.03 53.33). Then $\mathrm{H}_{3}$ should be rejected (Han \& Qiu, 2007; Opler et al., 1999).

Similarly to the direct effect between the NTC and CH shows the relationship positively insignificant 0.283 (p> $0.05)$ with $(95 \%$ confidence interval $-0003 \sim 0011)$, then $\mathrm{H}_{4}$ must be rejected. Agreeing with Bayyurt \& Nizaeva 
(2016), their research in Turkey found an insignificant relationship between NTC and CH. The direct effect between SZ and $\mathrm{CH}$ showed an insignificant negative relationship 0.06 ( $\mathrm{p}>0.05)$ with $(95 \%$ confidence interval $-0.301 \sim$ 0.006). Then $\mathrm{H}_{5}$ should be rejected. Likewise, the research results from Christian \& Fauziah (2017), in several nonfinancial companies in Indonesia found that SZ hurt $\mathrm{CH}$. At the same time, the direct effect between $\mathrm{NWC}$ and $\mathrm{CH}$ shows a positive and insignificant relationship of 0.49 ( $p>0.05)$ with $(95 \%$ confidence interval $-1.67 \sim 3.44$, so $\mathrm{H}$ ${ }_{6}$ must be accepted. These results agree with Ali et al. (2016), research on 30 textile companies in Pakistan. Similarly, the results of the analysis between $\mathrm{CH}$ and ROA show a significant positive relationship of 0.028 ( $\mathrm{p}>0.005$ ) with (95\% confident interval $0.47 \sim 7.68$ ), so $\mathrm{H}_{7}$ can be accepted.

Table 2

Analysis between $\mathrm{CH}$ and $\mathrm{ROA}$

\begin{tabular}{ccccc}
\hline Influence & Path Coefficient & Prob. & & Description \\
\hline NTC $\rightarrow \cdot$ ROA & -0.04 & 0.350 & Negative & Not significant \\
SZ $\rightarrow \cdot$ ROA & -0.49 & 0.620 & Negative & Not significant \\
NWC $\rightarrow \cdot$ ROA & 22.15 & 0.159 & Positive & Not significant \\
NTC $\rightarrow \cdot$ CH & 0.004 & 0.283 & Positive & Not significant \\
SZ $\rightarrow \cdot$ CH & -0.147 & 0.060 & Negative & Not significant \\
NWC $\rightarrow \cdot$ CH & 0.884 & 0.490 & Positive & Not significant \\
CH $\rightarrow \cdot$ ROA & 4.074 & 0.028 & Positive & Significant \\
\hline
\end{tabular}

The mediating effect was further investigated using 5000 bootstrap samples with $95 \%$ confidence intervals, and the results showed that cash holdings did not significantly mediate the relationship between NTC, SZ, NWC, and ROA. The indirect effect of NTC on ROA through $\mathrm{CH}$ is 0.0167 and is not significant at a $5 \%$ p-value (bootstrapping interval between $-0.0022 \sim 0.0775$ ). Then $\mathrm{H}_{8}$ must be rejected (Raffo, 2008; Hommes, 1995). The indirect effect of $\mathrm{SZ}$ on ROA through $\mathrm{CH}$ is -0.6086 and not significant at a $5 \%$ p-value (bootstrapping interval between $-1.0746 \sim$ 0.8047), so $\mathrm{H}_{9}$ is acceptable. Moreover, the indirect effect of $\mathrm{NWC}$ on ROA through $\mathrm{CH}$ is 3.3933 and not significant at a $5 \%$ p-value (bootstrapping interval between -1.1620 24.6656). Then $\mathrm{H}_{10}$ can be accepted.

Table 3

Indirect effect of NWC on ROA through $\mathrm{CH}$

\begin{tabular}{ccccc}
\hline Influence & Path Coefficient & Prob. & & Description \\
\hline NTC $\rightarrow \cdot \mathrm{CH} \rightarrow \cdot$ ROA & 0.0167 & 1.10 & Positive & Not significant \\
SZ $\rightarrow \cdot \mathrm{CH} \rightarrow \cdot$ ROA & -0.6086 & -0.137 & Negative & Not significant \\
NWC $\rightarrow \cdot \mathrm{CH} \rightarrow \cdot$ ROA & 3.3933 & 0.606 & Positive & Not significant \\
\hline
\end{tabular}

\section{Conclusion}

Empirical evidence based on SPSS shows that the Net Trade Cycle has a direct negative and insignificant effect on ROA. Meanwhile, Firm Size and Net Working Capital have a positive and significant impact on ROA. For the indirect effect, the results of the 5000 bootstrap sample also provide empirical evidence that the Net Trade Cycle and Net Working Capital have an insignificant positive effect on ROA through Cash Holdings. Meanwhile, Firm size has no significant adverse effect on ROA through cash holdings (Suryanata et al., 2018; Putra et al., 2020). The study concludes that the level of cash holdings cannot mediate the effect of the net trade cycle, firm size, and networking capital on cement-producing companies' profitability in Indonesia. Likewise, without the mediation of cash holdings, the relationship between net trade cycle, firm size, and networking capital have no significant effect on ROA as a proxy for profitability. Therefore, this study helps us understand how far the effect of fluctuations in net working capital and net trade cycle and the trend of growth in company size on the ROA level of cement producing companies in Indonesia (Baños-Caballero et al., 2014; Aktas et al., 2015).

\section{Acknowledgments}

The author expresses his deep gratitude for all the support in feedback and funding sponsors from the old government through Purwantini, where we have a career. Without the support and assistance and attention of all of the above, it seems that this study cannot be carried out as expected. 


\section{References}

Aktas, N., Croci, E., \& Petmezas, D. (2015). Is working capital management value-enhancing? Evidence from firm performance and investments. Journal of Corporate Finance, 30, 98-113. https://doi.org/10.1016/j.jcorpfin.2014.12.008

Ali, M., Kan, K. A. S., \& Sarstedt, M. (2016). Direct and configurational paths of absorptive capacity and organizational innovation to successful organizational performance. Journal of business research, 69(11), 53175323.

Baños-Caballero, S., García-Teruel, P. J., \& Martínez-Solano, P. (2014). Working capital management, corporate performance, and financial constraints. Journal of Business Research,67(3), 332-338. https://doi.org/10.1016/j.jbusres.2013.01.016

Begley, T. M., \& Boyd, D. P. (1987). Psychological characteristics associated with performence in entrepreneurial firms and smaller businesses. Journal of business venturing, 2(1), 79-93. https://doi.org/10.1016/08839026(87)90020-6

Burawoy, M. (2009). The extended case method. University of California Press.

Campbell, S. (2014). What is qualitative research?. Clinical Laboratory Science, 27(1), 3.

Chistian, N., \& Fauziah, F. (2017). Faktor-faktor penahanan dana (cash holding). Global Financial Accounting Journal, 1(1), 13-24.

Dongxue, L., Xinhua, F., Xuequan, W., \& Mingshu, T. (1997). Durability study of steel slag cement. Cement and Concrete Research, 27(7), 983-987. https://doi.org/10.1016/S0008-8846(97)00084-7

Han, S., \& Qiu, J. (2007). Corporate precautionary cash holdings. Journal of corporate finance, 13(1), 43-57. https://doi.org/10.1016/j.jcorpfin.2006.05.002

Heale, R., \& Twycross, A. (2015). Validity and reliability in quantitative studies. Evidence-based nursing, 18(3), 6667.

Hommes, C. H. (1995). A reconsideration of Hicks' non-linear trade cycle model. Structural change and economic dynamics, 6(4), 435-459. https://doi.org/10.1016/0954-349X(95)00032-I

Kawakibi, A. A., \& Hadiwidjojo, D. (2019). The Effect Of Working Capital Management On Company Profits And Values (Study Of Cement Companies Listed On The Indonesia Stock Exchange).

Kim, K. (2019). Using partially state-owned enterprises for development in Indonesia. Asia Pacific Business Review, 25(3), 317-337.

Lepetit, L., \& Strobel, F. (2013). Bank insolvency risk and time-varying Z-score measures. Journal of International Financial Markets, Institutions and Money, 25, 73-87. https://doi.org/10.1016/j.intfin.2013.01.004

Nijam, H. M. (2016). Cash conversion cycle, its properties and profitability: Evidence from listed hotel companies in Sri Lanka. Cash Conversion Cycle, Its Properties and Profitability: Evidence from Listed Hotel Companies in Sri Lanka. Research Journal of Finance and Accounting, 7(1), 23-32.

Niresh, A., \& Thirunavukkarasu, V. (2014). Firm size and profitability: A study of listed manufacturing firms in Sri Lanka. International journal of business and management, 9(4).

Opler, T., Pinkowitz, L., Stulz, R., \& Williamson, R. (1999). The determinants and implications of corporate cash holdings. Journal of financial economics, 52(1), 3-46. https://doi.org/10.1016/S0304-405X(99)00003-3

Prabowo, F. A., \& Rusdiansyah, A. (2018). Ebitda Gain Optimization Using Strategy Allowcation Of Market Share Distribution In Xyz Company: A Case Study In Indonesia.

Putra, M. D. P., Widanaputra, A. A. G. P., Ramantha, I. W., \& Gayatri, G. (2020). The effect of organizational commitments in auditor performance with dysfunctional audit behavior as mediation variables. International Research Journal of Management, IT and Social Sciences, 7(1), 45-52. https://doi.org/10.21744/irjmis.v7n1.812

Qu, S. Q., \& Dumay, J. (2011). The qualitative research interview, Qual. Res. Account. Manage., 8, $238-264$.

Raffo, A. (2008). Net exports, consumption volatility and international business cycle models. Journal of International Economics, 75(1), 14-29. https://doi.org/10.1016/j.jinteco.2007.10.001

Shiqun, L., Jiashan, H., Biao, L., Guohui, Z., Wei, C., Qi, W., \& Ning, Z. (1999). Fundamental study on aluminophosphate cement. Cement and concrete research, 29(10), 1549-1554. https://doi.org/10.1016/S00088846(99)00111-8

Subiyanto, E. (2020). A failure innovation strategy of acquisition during excess capacity: financial approach based on case study at the state-owned cement holding PT Semen Indonesia (Persero) Tbk. Journal of Innovation and Entrepreneurship, 9(1), 1-14.

Suryanata, I. G. N. P., \& Pemayun, A. G. P. (2018). Contribution of business society credit increasing for society income: Tambawu village Denpasar Bali. International Research Journal of Management, IT and Social Sciences, 5(4), 71-79. https://doi.org/10.21744/irjmis.v5n4.265 
Tawfeeq, A. A., Mahdi, M. F., Abaas, I. S., \& Alwan, A. H. (2018). Isolation, quantification, and identification of rosmarinic acid, gas chromatography-mass spectrometry analysis of essential oil, cytotoxic effect, and antimicrobial investigation of Rosmarinus officinalis leaves. Asian J Pharm Clin Res, 11(6), 126-132.

Yilmaz, I., \& Acar, G. (2019). The effect of cash conversion cycle on profitability in Omani companies. International Journal of Economics, Management and Accounting, 27(2), 269-290. 